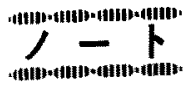

(1998年3月30日受付・1998年11月10日受理)

\title{
酵素系漂白剤処理綿布の風合い評価
}

\author{
北海道教育大学岩見沢校 小竹森路子・藤本尊子 \\ 北海道教育大学札幌校 小松恵美子・山口江利子・森田みゆき
}

\section{Evaluation of Hand Values of Cotton Weaves Treated by Enzyme Bleaching Agents.}

\author{
Michiko Kotakemori*1, Takako Fujimoto ${ }^{* 1}$, Emiko Komatsu*2, \\ Eriko Yamaguchi ${ }^{* 2}$ and Miyuki Morita ${ }^{* 2}$
}

\author{
${ }^{* 1}$ Hokkaido University of Education, Iwamizawa, Iwamizawa-shi, 068-8642 Japan \\ ${ }^{* 2}$ Hokkaido University of Education, Sapporo, Kita-ku, Sapporo-shi, 002-8502 Japan
}

\begin{abstract}
Bleaching system applying horseradish peroxidase(HRP) was lately attracted industrial attention for its economizing energy and its significancy to protect the dye transfer. Since fabric mechanical properties should change during processing chemical treatment, it is worth to examine how the physical property changed. And this topic might be most important from the view point of fabric end-use. The fabric physical quality was evaluated objectively on the unfinished/finished cotton fabrics by using mechanical properties such as tensile, bending, shear, compressional and surface properties from the measurement. Unfinished sample and samples finished with two kinds of bleached system were prepared: one with a mixture of horseradish peroxidase (HRP) and hydrogen peroxide $\left(\mathrm{H}_{2} \mathrm{O}_{2}\right)$ and the other with percarbonate. Fabric mechanical properties and hand values derived from physical values were compared among samples and discussed the effect of each systems on the fabric quality. A mixture of horseradish peroxidase (HRP) and hydrogen peroxide $\left(\mathrm{H}_{2} \mathrm{O}_{2}\right)$ system reduced the fabrics hairiness and protected the disordering of intra -yarn. These structural change would reflect the high performance of handle values, which was higher than that of the other samples.
\end{abstract}

(Received 30 March, 1998 ; Accepted 10 November, 1998)

\section{1. 緒 言}

過炭酸ナトリウムなどの酸素系漂白剤の使用量は年々 增加しているが[1]，これを用いた色移り防止条件は，高 アルカリ，高温ななめ，㰇維の脆化[2]およびエネルギー コストに開題があるといわれていた[3].

近年, HRP(西洋わさび由来のペルオキシダーゼ)柔漂

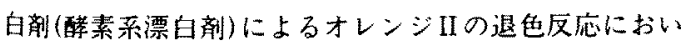
て, 退色速度が過炭酸ナトリウム(従来の漂白郕)を用い た場合より大幅に增大し、ナイロン染色布では变退色せ ず,挠維の性能変化も起こらないことが報告された[4-6]. 色移り現象を防止することは，衣服の管理上重要な課題
であり、この漂白戍の開発および塞用化は，䒚方面から 期待されているところである。

化学的な影響に对して一方では，布は衣服を形成する 材料としてその力学的性質は実用上極めて重要であり， 布の性質は諸物理量や風合いとして総合的に携えること が要請される、䄉維生地の改善を目的としたセルラーゼ, プロテアーゼの利用は、䣼素の洗剤への活用に続き急速 に增大しており，それについての研究も增之ている $[7,8]$. しかし，それら化学的処理に伴う風合い変化について総 合的に評価されている文献は少ない[8-11]. 最近, 盛と 芳賀[12]が，七ルラーゼ処理によるセルロース采就維布 の改質について，風合いの観点から報告していることは 
着目される。

本報では、綿布のHRP系漂白処理による諸力学的性質 ならびにそれらから算出される風合い值を調べ，従来法 である過炭酸ナトリウム系漂白処理の諸力学的性犋なら びに風合い值と比較・椧討した。この結果は，今後この 醉素系漂白剂を用いた洗浄過程での衣料の性能変化を適 切に示す基礎を提供するものである。

\section{2. 実験}

\section{1 試薬}

オレンジIIは和光純薬の試薬を再結晶法で精製し， 口 紙分配クロマトグラムとUVスペクトルで純度を確認して 使用した. 西洋わさび由来のペルオキシダーゼ(HRP)は 和光純薬慗(生化学用)を使用した.HRPの濃度はモル吸 光係数 $1.02 \times 10^{5} \mathrm{~mol}^{-1} \mathrm{dm}^{3} \mathrm{~cm}^{-1}(403 \mathrm{~nm})$ [13] 老用いて 算出し，母液 $\left\{1.64 \times 10^{-4} \mathrm{M}\left(=\mathrm{mol} \mathrm{dm}{ }^{-3}\right)\right\}$ を使用值前に 希釈して使用した. $\mathrm{H}_{2} \mathrm{O}_{2}$ は和光純薬の武薬特級を使用し た. $6.7 \times 10^{-2} \mathrm{M}$ 過炭酸ナトリウムは溶液は使用直前に $1.34 \times$

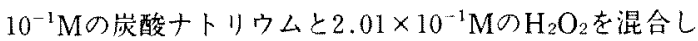
て調製しな、調製には0.1Mリン酸緩衝液(pH11.5)を使用 した，そのほかの試薬は全て市販の特級品を使用し，水 沬イオン交換水を 1 回蒸留し,ミリポアで超純水処理し たものを用いた。

\section{2 綿布}

綿布は実験用平織地を使用した。綿布はエタノールー 水 $(=1: 1(\mathrm{v} / \mathrm{v}))$ 混合溶液中で水溶性成分を除去した後, 風乾したものを前処理布とした．また，前処理を行って いない綿布老、本論文中では未処理布と呼ぶこととする。

\section{3 操作法}

\subsection{1 綿布の漂白}

前処理布 $20 \mathrm{~g}$ を゙ーカーに入れ，浴比が1：50となるよ

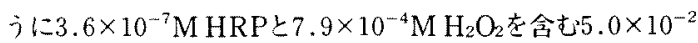
Mトリ又一 $\mathrm{HCl}$ 緩衝溶液 $(\mathrm{pH} 9.0) 950 \mathrm{~cm}^{3}$ を加之，㨨抖を

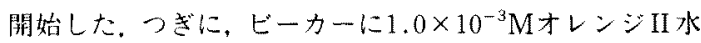
溶液を $50 \mathrm{~cm}^{3}$ 加之, $20^{\circ} \mathrm{C} て ゙ 30$ 分閒反応を行った。 反応後, 取り出した綿布を風乾した，以上の操作を10回繰り返し た。

過炭酸ナトリウム系漂白郕を用いる場合には，HRPと $\mathrm{H}_{2} \mathrm{O}_{2}$ を含む十リスー $\mathrm{HCl}$ 䌅衝液のかわりに, $6.7 \times 10^{-2} \mathrm{M}$ 過炭酸ナトリウム溶液 $950 \mathrm{~cm}^{3}$ をビーカーに加えて、同様 の操作で70豆で実験を行った。

\subsection{2 䄸布の表面特性, 諸力学特性の測定}

試料布 3 枚について観察，計測を行った，表面特性は， ニコン社製OPTIPHOT金属顕徽鏡および尃用写真撮影装 置にて表面観察をおこなった。

布の諸力学特性(引張り，曲げ，女ん断，压縮，表面特
性㧍よび重量)はKES一FB計測システムを用いて，標隼 高感度測定条件で, 標準状態 $\left(20^{\circ} \mathrm{C}, 65 \% \mathrm{RH}\right)$ にて即定を 行った。さらに，各特性值から $\mathrm{KN}-203-\mathrm{LDY}$ 式[14] を用いて，KOSHI(stiffness), NUMERI (smoothness), FUKURAMI(fullness), T.H.V (total hand value) を求地, 母平均值差の評洒は危険率 $5 \%$ で有意な差のあるものを 採用し考察した。

\section{3. 結果および考察}

\section{1 顕微鏡による表面観察}

綿布の漂白処理条件は，綿布に対しHRPおよび過炭酸 ナトリウムによる色移り防止の漂白処理の最適条件[5]て 行った.Fig.1は未処理布と過炭酸ナトリウム漂白剂処理 布およびHRP漂白処理布の写真である。これらを比䩪才 ると(c)のHRP漂白処理布においては，織系の膨張が見ら れず然りが堅く糸が締まっており，(a)の末処理布に近い 状態であったこれに対し(b)の過炭酸ナトリウム漂白削 処理布では瀻維が毛羽立っており，織糸か膨張していた， 表面に瀻維がはぐれてはみだし，ランダムに絡み合った 毛羽の層が観察された。糸を形成している载維し楴まり がなく, 見かけの太さもHRP漂白処理, 未処理に比へて 太くなっていた，過炭酸ナトリウム処理布の系に上嗵の ような構造の乱れが生じたのは, 温度あるいはpHの影暨 か化学種の影響かは明確ではないが，同一の機械力を加 えたのに関わらす過炭酸ナトリウム処理よりもHRP処理 の方が布表面の構造に影響がないことが明らかとなった。 織密度の差は見られなかった，洗浄操作など布の浸漬战 より布表面に毛羽立ちが生ずる[15]。過炭酸ナトリウム では毛羽立ちが生し，通常の洗浄結果と同梯の結果が得 られた，己らに基本構造特性值のうち見かけ比重の值は 過炭酸ナトリウム布では有意に原布より隇少した，した がって, 䋐維の体積分率も減少しており，有効熱伝導事 は大きくなった，HRP処理布では，そのような变化か㵊 められなかったＩshiiらによるシノン布の醉素処理によ る詳細な緎維形態観察に関する研究では[16,17],载維の マイクロボイドが構造特性值に重要な影響を与えていた。 本研究に扔いても，処理による織維形態の変化およびを れにおよぼす処理濃度や時間の影響を、今後詳細に調へ ることが要請される。

\section{2 諸力学特性および風合いの变化}

Fig.2に測定した諸力学特性とそれらからKN-203-LDY の式を用いて算出した風合い值をチャート上に示した。 各処理とも縦横方向の平均值をプロットした，前揭の写 真で観察された結果を反映して，過炭酸ナトリウム処理 布では厚さTは原布より大きくなる。それに対しHRP漂 白処理布はやや原布より大きくなり，表面特性で平均摩 


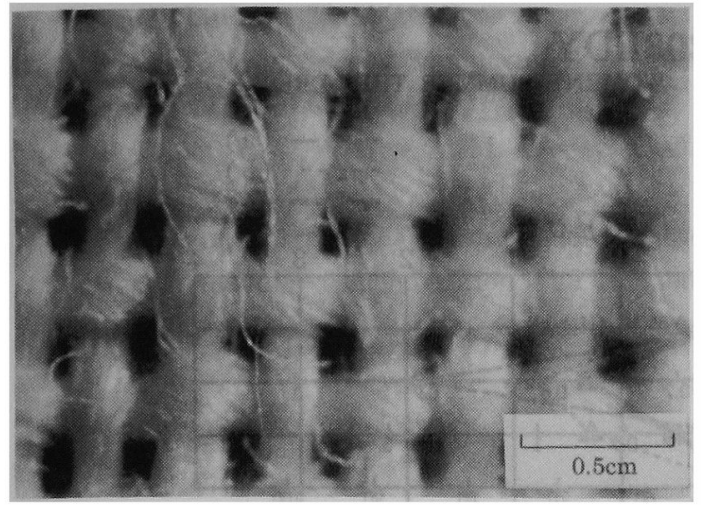

\section{( a )}

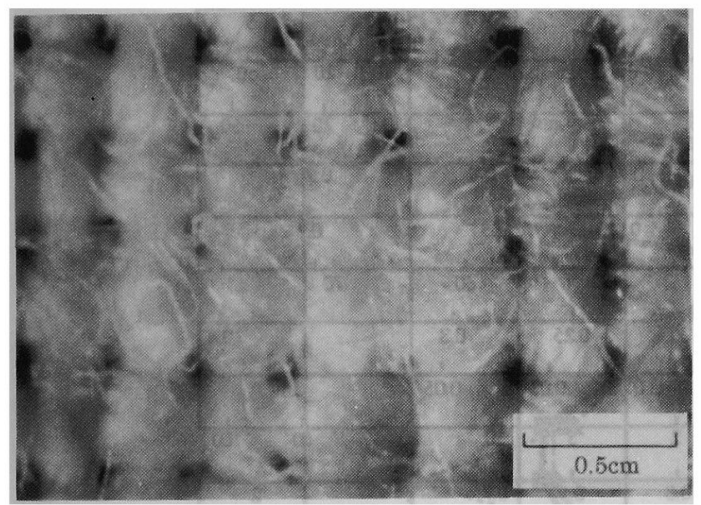

( b )

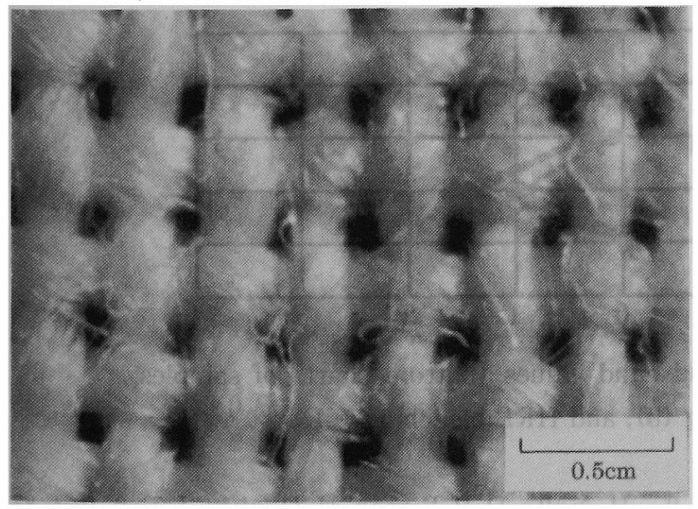

(c )

Fig. 1 Micrographs of surface of cotton weaves with unfinished (a), percarbonate bleaching (b) , and HRP bleaching (c) .
擦特性MIUがやや增加, 摩擦係数の変動MMDが小さいこ とから表面が平滑になっていることが現れている，過炭 酸ナトリウム処理によって厚さが増した結果は,これま で報告された[18]ステープル布での洗濯処理での繊維集 束の乱れがそれを招くことと一致する。しかし，HRP処 理にはこの現象が生じず，この酵素漂白系の家庭洗剤へ の配合による製織仕上げ時の加工風合いの維持の可能性 を示唆する. 曲け剛性Bやせん断剛性Gは, 両処理により 原布よりもやわらかくヒステリシスも小さくなり，弾性 的になることがわかる，引張り特性については，両処理 の影響がほかの力学量にくらべ大きく現れた．最大荷重 $50 \mathrm{gf} / \mathrm{cm}$ までの伸長率EMは両処理とも末処理に比べ増加 し, HRP処理布では縦横方向平均で約1.58倍増加し, 過 炭酸ナトリウム処理布で2.99倍になっている.引張り变 形過程のエネルギー量WTは，過炭酸ナトリウム処理布 (b)では未処理布 (a) と比較して 2 倍以上の值を示す。そ れに比べHRP処理布 (c)では1.4倍の増加であり，危険率 $5 \%$ で有意な差か確認された。

また，諸力学特性值から変換式を用いて算出される風 合い值 (Fig.2)では，過炭酸ナトリウム処理をすると FUKURAMIが上がりKOSHIや総合風合い值T.H.Vが下 がるという变化をもたらすが, HRP処理では未処理に比 べKOSHIが小さく，NUMERIが大きく，FUKURAMI が増す。これら基本風合い値を用いて算出される総合風 合い值T.H.Vでは未処理布とHRP処理との間には危険率 10\%で有意差が確認されT.H.Vが向上した．一方，過炭 酸ナトリウム処理ではT.H.Vは危険率 $5 \%$ で未処理布と の有意差か確認され低下した. 以上のことからHRPは移 染防止剤としての役割のほかに, 風合いの維持, 改善も できることが数量的に確かめられた，さらに高温，高ア ルカリで処理しなければならない過炭酸ナトリウムでの 漂白処理により脆化(かたくもろくなる)する[6]ことから， HRPによる漂白処理の方が優れていることか確認された.

なお本研究において, 観察装置の提供など終始御協力 いただいた北海道教育大学物理学志尾彌教授に謹んで感 謝申し上げます。

\section{文献}

1. D. M. Coons, J. Am. Oil Chem. Soc., 50, 104 (1978).

2. Y. Imabayashi, S. Yoshikawa, Sen'i Seihin Shohi Kagaku, 25, 400(1992).

3. S. Shikata, Sen'i Seihin Shohi Kagaku, 37, 53(1996).

4. M. Morita, R. Ito, T. Kamidate, H. Watanabe, Text. Res. J., 66, 470 (1996).

5. M. Morita, E. Komatu, T. Kamidate, H. Watanabe, 


\section{DATA CHART－203LDY}

WOMEN'S SUMMER THIN DRESS

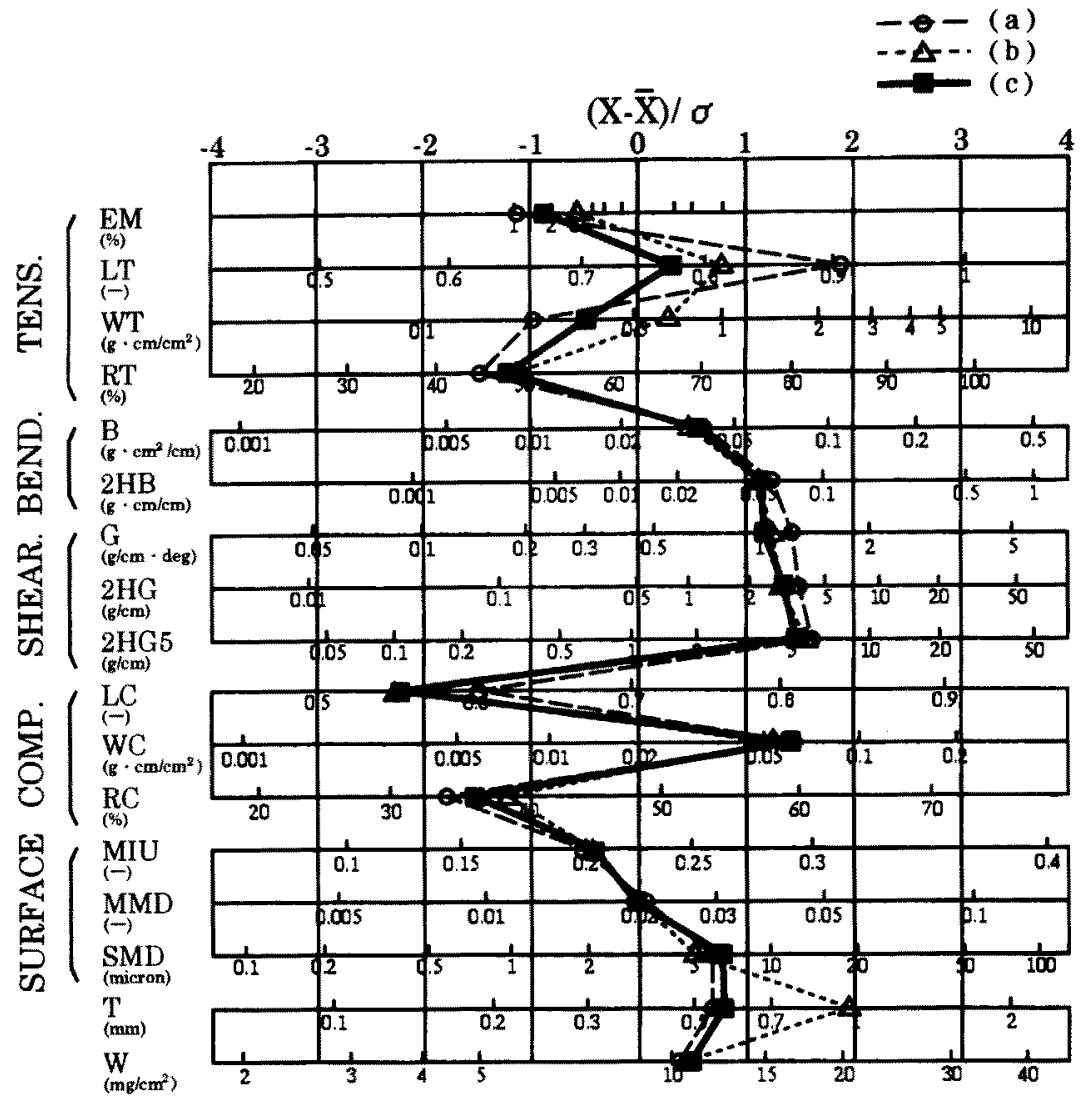

H.V.

KOSHI

NUMERI

FUKURAMI

T.H.V

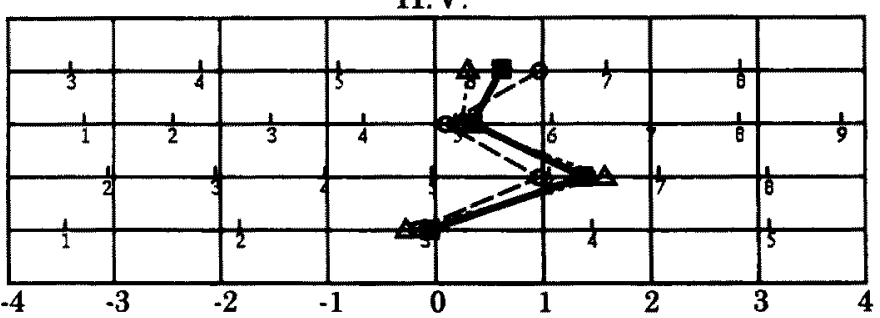

Fig. 2 Mechanical properties (top chart) and hand values (bottom chart) of samples: unfinished (a), percarbonate bleaching (b), and HRP bleaching (c).

Sen'i Gakkaishi, 53, 289 (1997).

6. M. Morita, E. Komatu, T. Kamidate, H. Watanabe,

Sen'i Gakkaishi, 53, 471 (1997).

7. K. Ishii, S. Oka, Sen'i Gakkaishi, 39, 479 (1983)

8. T. Kitaura, T. Amano, Sen'i Gakkaishi, 52, 441 (1996).
9. H. Nolte, D. P. Bishop, H. Hocker, J. Text. Inst., 87, $212(1996)$.

10. T. Ueshima, "Sangyoyo Koso", Maruzen, Tokyo (1995)

11. M. Yamagishi, Reports of the Shizuoka Prefectural Hamamatsu Textile Industrial 
Research Institute, 25, 11 (1986).

12. R. Mori, T. Haga, Special Seminar of University of New South Wales, Sydney (1997).

13. B. B. Kimm, V. V. Pisarev, A. M. Egorov, Anal. Biochem., 199, 1(1991).

14. S. Kawabata, "The Standardization and analysis of Hand Evaluation-second edition-", The Hand Evaluation and Standardization Committee, the
Textile Machinery Society (1980).

15. M. Niwa, T. Mamiya, K. Hurusato, Kaseigaku Zasshi, 29, 180 (1978).

16. K. Ishii, Sen'i Gakkaishi, 40, 322 (1984).

17. K. Ishii, Sen'i Gakkaishi, 44, 374(1988).

18. Y. Okamoto, M. Niwa, Sen'i Seihin Shohi Kagaku, 23, 293(1987). 